\title{
PENGARUH KUALITAS KEHIDUPAN KERJA DAN KEPUASAN KERJA TERHADAP KINERJA KARYAWAN PT PERTAMINA PERSERO RU IV CILACAP
}

\author{
Astrianditya Januar Ristanti \\ UII Yogyakarta \\ Fereshti Nurdiana Dihan \\ UII Yogyakarta \\ fereshtideevadha@gmail.com
}

\begin{abstract}
This study titled influence the quality of work life and job satisfaction on employee performance of PT Pertamina Persero RU Cilacap. The purpose of this study was to determine the effect on the quality of work life by partial performance, determine the effect of job satisfaction on performance partially, and determine the influence of the quality of work life and job satisfaction simultaneously on employee performance. The independent variable in this study is the quality of work life and job satisfaction, the dependent variable in this study is the performance. The population of this study were 600 permanent employees shift part of PT. Pertamina Persero RU Cilacap. Sampling technique using census sampling methods and techniques Probability Proportionate Random Sampling Strarified totaling 221 employees. Data collection method used was a questionnaire and the data mengalisis using the multiple linear regression analysis.

These results indicate that the quality of work life has significant influence but not the performance, job satisfaction has a significant impact on performance, while the quality of work life and job satisfaction has a significant impact on employee performance remains part of PT Pertamina Persero shift RU Cilacap.
\end{abstract}

Keywords: Quality of Work Life, Job Satisfaction, Performance

\section{PENDAHULUAN}

\section{Latar Belakang}

Sumber daya manusia merupakan faktor yang sangat berharga, maka perusahaan bertanggungjawab untuk memelihara kualitas kehidupan kerja dan membina tenaga kerja agar bersedia memberikan kontribusinya secara optimal untuk mencapai tujuan perusahaan (Pruijt, 2003). Pendapat lain menurut Cascio (2006) Kualitas kehidupan kerja mencakup aktifitasaktifitas yang ada di dalam perusahaan, yang diarahkan untuk meningkatkan suatu kondisi kehidupan kerja yang dapat membangkitkan semangat kerja dalam melaksanakan tugas mencapai sasaran perusahaan. Dalam hal ini penerapan teori Quality Of Work Life (QWL) dapat di aplikasikan untuk memperbaiki kualitas kehidupan para pekerja, tidak dibatasi pada perubahan konteks suatu pekerjaan tapi juga termasuk memanusiakan lingkungan kerja untuk memperbaiki martabat dan harga diri pekerja.

Selain Kualitas Kehidupan Kerja terdapat beberapa faktor lain yang perlu diperhatikan yaitu Kepuasan Kerja. Menurut Hasibuan (2013:202) Kepuasan Kerja dalam pekerjaan adalah kepuasan kerja yang dinikmati dalam pekerjaan dengan memperoleh pujian hasil kerja, penempatan, perlakuan, peralatan, dan suasana lingkungan kerja yang baik. Dalam hal ini sangat dibutuhkan budaya kerja yang baik sehingga karyawan merasa nyaman dalam lingkungan dan memiliki kualitas kehidupan kerja yang baik untuk dapat melaksanakan tugasnya dengan profesional sesuai dengan tujuan organisasi. 
Mangkunegara (2010) berpendapat bahwa kinerja adalah hasil kerja secara kualitas dan kuantitas yang dicapai oleh karyawan dalam melaksanakan tugasnya sesuai dengan tanggung jawab yang diberikan kepadanya. Jika karyawan memiliki kepuasan kerja yang tinggi, maka secara langsung karyawan akan loyal terhadap organisasi dan kinerja menjadi semakin meningkat.

Bhe \& Rose (2007) dalam penelitiannya menyimpulkan bahwa QWL dan kinerja memiliki indikator utama dalam kinerja yakni konsistensi, effort, waktu, pekerjaan, kompetensi, komitmen, dan excel, sedangkan pada QWL yakni kapasitas, keamanan, komunikasi, peran, benefit, kepuasan, dan keadilan. Karyawan merupakan aset yang berharga yang dimiliki oleh perusahaan, berhasilnya suatu produk di pasaran dapat dinilai dari kualitas perusahaan. Kinerja karyawan menjadi sangat penting untuk kemajuan perusahaan di samping strategi dan produk yang inovatif. Kinerja yang baik dipengaruhi oleh kepuasan kerja yang didapatkan diperusahaan tersebut. Dengan kata lain, perusahaan yang berkualitas adalah perusahaan yang memiliki kualitas hidup kerja yang baik, bisa mensejahterakan karyawan sehingga menghasilkan karyawan yang berkualitas dan berkompeten.

Dalam penanganan masalah organisasi, peneliti tertarik untuk meneliti beberapa variabel tentang Kualitas Kehidupan Kerja (Quality of Work Life), Kepuasan Kerja dan Kinerja Karyawan di internal kantor PT Pertamina Persero RU IV Cilacap, bagaimana memberikan pelayanan dan fasilitas yang baik kepada karyawan agar membentuk karyawannya menjadi karyawan yang efektif, efisien, dan juga produktif dengan tidak melupakan bagaimana kesejahteraan mereka dalam bekerja. Dan memberikan kenyamanan kepada karyawan agar merasa dihargai dalam pekerjaannya sehingga menimbulkan kepuasan dalam bekerja dan meningkatkan kinerja yang baik bagi karyawan. Dari variabel tersebut diatas maka peneliti mengangkat judul tentang "Pengaruh Kualitas Kehidupan Kerja dan Kepuasan Kerja Terhadap Kinerja Karyawan PT Pertamina Persero RU IV Cilacap”.

\section{KAJIAN PUSTAKA \\ Kualitas Kehidupan Kerja}

Menurut Walton (1974) kualitas kehidupan kerja merupakan persepsi pekerja terhadap suasana dan pengalaman pekerja ditempat kerja mereka. Pendapat lain menurut Cascio (1998) bahwa secara teori, QWL sederhana yaitu melibatkan memberikan pekerja kesempatan untuk membuat keputusan tentang pekerjaan mereka, desain tempat kerja mereka, dan apa yang mereka butuhkan untuk membuat produk atau memberikan layanan yang paling efektif. Indikator dalam kualitas kehidupan kerja menurut Walton ( 1974 , dalam Zin 2004 ) antara lain 1) Pertumbuhan dan pengembangan, yaitu terdapatnya kemungkinan untuk mengembangkan kemampuan dan tersedianya kesempatan untuk menggunakan ketrampilan atau pengetahuan yang dimiliki karyawan. 2) Partisipasi, yaitu adanya kesempatan untuk berpartisipasi atau terlibat Dalam pengambilan keputusan yang mempengaruhi langsung maupun tidak langsung terhadap pekerjaan. 3) Sistem imbalan yang inovatif, yaitu bahwa imbalan yang diberikan kepada karyawan memungkinkan mereka untuk memuaskan berbagai kebutuhannya sesuai dengan standard hidup karyawan yang bersangkutan dan sesuai dengan standard pengupahan dan penggajian yang berlaku di pasaran kerja. 4) Lingkungan kerja, yaitu tersedianya lingkungan kerja yang kondusif, termasuk di dalamnya penetapan jam kerja, peraturan yang berlaku kepemimpinan serta lingkungan fisik. 


\section{Kinerja}

Bernardin dan Russel (2003) memberikan pengertian kinerja sebagai berikut : "performance is defined as the record of outcomes produced on a specified job function or activity during time period". Prestasi atau kinerja adalah catatan tentang hasil-hasil yang diperoleh dari fungsi-fungsi pekerjaan tertentu atau kegiatan selama kurun waktu tertentu. Untuk mengukur kinerja karyawan, dapat digunakan beberapa dimensi mengenai kriteria kinerja yang menurut Bernardin \& Russel (2003: 135) adalah sebagai berikut 1) Kualitas (Quality), yaitu merupakan tingkatan dimana proses atau hasil dari penyelesaian suatu kegiatan mendekati sempurna. 2) Kuantitas (Quantity), yaitu merupakan produksi yang dihasilkan dapat ditunjukkan dalam satuan mata uang, jumlah unit, atau jumlah siklus kegiatan yang diselesaikan. 3) Ketepatan waktu (timelinnes), yaitu merupakan dimana kegiatan tersebut dapat diselesaikan, atau suatu hasil produksi dapat dicapai, pada permulaan waktu yang ditetapkan bersamaan koordinasi dengan hasil produk yang lain dan memaksimalkan waktu yang tersedia untuk kegiatan-kegiatan lain. 4) Efektivitas biaya (cost effectivennes), yaitu merupakan tingkatan dimana sumber daya organisasi, seperti manusia, keuangan, teknologi, bahan baku dapat dimaksimalkan dalam arti untuk memperoleh keuntungan yang paling tinggi atau mengurangi kerugian yang timbul dari setiap unit. 5) Kebutuhan akan pengawasan (need for supervision), yaitu merupakan tingkatan dimana seorang karyawan mampu melaksanakan suatu fungsi pekerjaan tanpa membutuhkan bantuan pengawasan atau memerlukan campur tangan pengawas untuk mencegah agar hasil produksi tidak mengalami kerugian. 6) Hubungan antar perseorangan (Interpersonal impact), yaitu merupakan tingkatan dimana seorang karyawan mampu untuk mengembangkan perasaan saling menghargai, niat baik, dan kerjasama antara karyawan yang satu dengan yang lain, dan juga pada bawahan.

\section{Kepuasan Kerja}

Menurut pendapat Robbins (2002:91) istilah kepuasan kerja merujuk kepada sikap umum seorang individu terhadap pekerjaan yang dilakukannya. Seseorang dengan tingkat kepuasan kerja tinggi menunjukan sikap yang positif terhadap kerja itu; seseorang yang tidak puas dengan pekerjaannya menunjukan sikap yang negatif terhadap pekerjaan itu. Karena pada umumnya apabila orang berbicara mengenai sikap karyawan, lebih sering mereka memaksudkan kepuasan kerja. Sedangkan menurut Smith, (dalam Robbins, 2002) menyatakan terdapat 5 dimensi yang mempengaruhi respon afektif seseorang terhadap pekerjaannya, yaitu 1) Pekerjaan itu sendiri, yaitu sejauh mana pekerjaan menyediakan kesempatan seseorang untuk belajar memperoleh tanggung jawab dalam suatu tugas tertentu dan tantangan untuk pekerjaan yang menarik. 2) Bayaran, yaitu upah yang diperoleh seseorang sebanding dengan usaha yang dilakukan dan sama dengan upah yang diterima oleh orang lain dalam posisi kerja yang sama. 3) Kesempatan untuk promosi, yaitu kesempatan seseorang untuk meraih atau dipromosikan ke jenjang yang lebih tinggi dalam organisasi. 4) Atasan, yaitu kemampuan atasan untuk memberikan bantuan tehnis dan dukungan terhadap pekerjaan yang menjadi tanggung jawab para bawahan. 5) Rekan kerja, yaitu sejauh mana rekan kerja secara tehnis cakap dan secara social mendukung tugas rekan kerja lainnya. 


\section{Tinjauan Penelitian Terdahulu}

Penelitian yang dilakukan ole Beh \& Rose (2007) yakni mengenai Linking $Q W L$ and Job Performance: Implicationts for Organization. Penelitian ini memiliki kontribusi besar pada literature kualitas kehidupan kerja melalui pengujian antar hubungan antar $Q W L$ dan job performance dengan survey kuisioner pada 475 sampel kepada para manajer manafaktur di Malaysia. Hasil penelitianya ialah mengindikasikan hubungan positif antar $Q W L$ dan $J o b$ Performance. Metode peneltian ini menggunakan structural equation modeling (SEM) dan menunjukan hasil dimana tingginya korelasi $(\mathrm{r}=0.94)$. Riset sangat memiliki manfaat terutama untuk perkembangan ilmu organisasi.

Penelitian yang dilakukan oleh Ahmad, Ing \& Bujang (2014) dengan judul "Relationship Between Selected Factors of Job Satisfaction and Job Performance Among Workers at Palm Oil Industries" mengidentifikasi hubungan antara faktor-faktor yang dipilih kepuasan kerja dan kinerja. Faktor-faktor kepuasan kerja yang meneliti dalam penelitian ini termasuk membayar, pekerjaan itu sendiri, promosi, supervisi, dan rekan kerja. Instrumen penelitian untuk penelitian ini digunakan kuesioner untuk mengumpulkan data dari responden. Temuan dalam penelitian ini menunjukkan bahwa ada hubungan yang signifikan antara faktor yang dipilih kepuasan kerja dan kinerja.

Arifin (2012) dalam jurnalnya yang berjudul "Analisis Kualitas Kehidupan Kerja, Kinerja, dan Kepuasan Kerja Pada CV Duta Senenan Jepara” Penelitian ini bertujuan untuk menganalisis pengaruh kualitas kehidupan kerja terhadap kinerja karyawan, menganalisis pengaruh kualitas kehidupan kerja terhadap kepuasan kerja, dan menganalisis pengaruh kepuasan kerja terhadap kinerja karyawan. Penelitian ini menyimpulkan bahwa kualitas kehidupan kerja sangat berpengaruh terhadap kinerjanya; kepuasan berpengaruh terhadap kinerja karyawan dan kualitas kehidupan kerja tidak berpengaruh terhadap kepuasan karyawan.

Sumbangan penelitian yang akan dilakukan yaitu dengan menggabungkan variabel kualitas kehidupan kerja, kepuasan kerja, dan kinerja. Penelitian ini bermaksud untuk mengetahui pengaruh masing-masing variabel tersebut pada perusahaan. Penelitian ini dilakukan di PT Pertamina Persero RU IV Cilacap yang belum pernah dilakukan oleh penelitian sebelumnya.

\section{Hipotesis}

Berdasarkan latar belakang dan tujuan penelitian di PT Pertamina Persero RU IV Cilacap, hipotesis yang diajukan adalah 1) Terdapat pengaruh positif dan signifikan antar variabel kualitas kehidupan kerja terhadap kinerja karyawan. 2) Terdapat pengaruh positif dan signifikan antar variabel kepuasan kerja terhadap kinerja karyawan. 3) Terdapat pengaruh positif dan signifikan antar variabel kualitas kehidupan kerja dan kepuasan kerja secara simultan terhadap kinerja karyawan.

\section{Kerangka Konseptual}

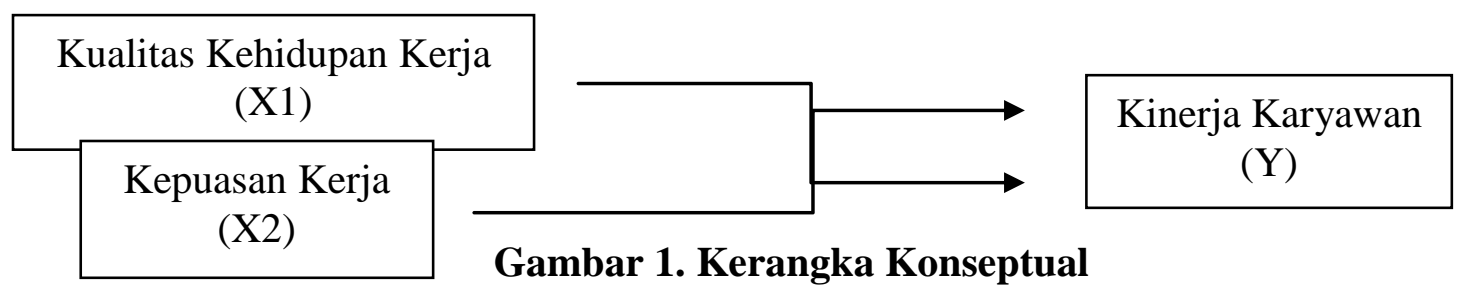




\section{METODOLOGI PENELITIAN}

\section{Lokasi Penelitian}

Dalam penelitian ini, lokasi yang dipilih oleh penulis adalah PT Pertamina Persero RU (Refinery Unit) IV Cilacap, yang merupakan Badan Usaha Milik Negara (BUMN) yang bergerak pada bidang usaha energi dan petrokimia. Dalam menjalankan kegiatan bisnisnya, PT Pertamina RU IV Cilacap menjalankan berdasarkan prinsip-prinsip tata kelola korporasi yang baik sehingga dapat berdaya saing yang tinggi dalam era globalisasi. PT Pertamina Persero RU IV Cilacap terletak di Jl. Letjen Haryono MT. 77 Lomanis, Cilacap Jawa Tengah 53221. Telp/fax : (0282) 531051 / (0282) 531284.

\section{Pendekatan Penelitian}

Penelitian yang digunakan menggunakan metode kuantitatif. Metode Penelitian Kuantitatif, sebagaimana dikemukana oleh Sugiyono (2009:14) dapat diartikan sebagai metode penelitian yang berlandaskan pada filsafat positivisme, digunakan untuk meneliti pada populasi atau sampel tertentu, teknik pengambilan sampel pada umumnya dilakukan secara random, pengumpulan data menggunakan instrumen penelitian, analisis data bersifat kuantitatif/statistik dengan tujuan untuk menguji hipotesis yang telah ditetapkan.

\section{Variabel Penelitian}

Variabel dalam penelitian ini adalah kualitas kehidupan kerja (X1) dan kepuasan kerja (X2) sebagai variabel independen. Kinerja Karyawan (Y) sebagai variabel dependen.

\section{Definisi Operasional Variabel}

Definisi Operasional dari variabel penelitian antara lain 1) Kualitas Kehidupan Kerja (X1) menurut Walton (1974) kualitas kehidupan kerja merupakan persepsi pekerja terhadap suasana dan pengalaman pekerja ditempat kerja mereka. 2) Kepuasan Kerja (X2) menurut pendapat Robbins (2002:91) istilah kepuasan kerja merujuk kepada sikap umum seorang individu terhadap pekerjaan yang dilakukannya. Seseorang dengan tingkat kepuasan kerja tinggi menunjukan sikap yang positif terhadap kerja itu; seseorang yang tidak puas dengan pekerjaannya menunjukan sikap yang negatif terhadap pekerjaan itu. 3) Kinerja (Y) menurut Bernardin dan Russel (2003) prestasi atau kinerja adalah catatan tentang hasil-hasil yang diperoleh dari fungsi-fungsi pekerjaan tertentu atau kegiatan selama kurun waktu tertentu.

\section{Jenis dan Teknik Pengumpulan Data}

Data primer yaitu data yang diperoleh dari tangan pertama untuk dianalisis berikutnya untuk menemukan solusi atau masalah yang diteliti (Sekaran, 2006:242). Pada penelitian ini, jenis data yang dikumpulkan adalah data primer, yaitu dengan menyebarkan kuesioner kepada karyawan tetap bagian shift pada PT Pertamina Persero RU IV Cilacap.

\section{Populasi dan Sampel}

Dalam penelitian yang dilakukan ini, populasinya seluruh karyawan tetap bagian shift PT Pertamina Persero RU IV Cilacap. Jumlah seluruh populasi karyawan tetap terdiri dari 19 bagian pekerja Shift dengan total 600 karyawan. Dengan pengambilan sampel 220 karyawan. Namun kuesioner yang dapat disebar sejumlah 210 dan yang kembali 171 kuesioner. 


\section{Metode Analisis Data}

Terdapat dua metode analisis data yang digunakan dalam penelitian ini yaitu berupa analisis deskriptif dan analisis statistika. Pada penelitian ini menggunakan analisis statistik dengan mode regresi linier berganda.

\section{HASIL ANALISIS DATA}

\section{Hasil Uji Instrumen}

Uji instrumen dalam penelitian ini menggunakan uji validitas dan reliabilitas. Hasil uji validitas pada pertanyaan kuesioner hasilnya secara keseluruhan valid. Sedangkan hasil uji reliabilitas secara keseluruhan reliabel.

\section{Analisis Deskriptif}

Penelitian ini melibatkan 171 responden dari seluruh karyawan tetap bagian shift PT Pertamina Persero RU IV Cilacap. Demografi responden yang mendominasi penelitian ini adalah berjenis kelamin pria sebanyak 169 orang, dengan usia 20-30 tahun sebanyak 60 orang, dengan pendidikan tamatan SMU/SMK sebanyak 69 orang serta masa kerja antara 2035 tahun sebanyak 48 orang.

\section{Tabel 1 Rekapitulasi Analisis Diskriptif Variabel Kualitas Kehidupan Kerja $\left(\mathbf{X}_{1}\right)$}

\begin{tabular}{|c|l|c|c|}
\hline No & \multicolumn{1}{|c|}{ Variabel } & Mean & Keterangan \\
\hline 1. & Kualitas Kehidupan Kerja $\left(\mathrm{X}_{1}\right)$ & 3,74 & Tinggi \\
\hline 2. & Pertumbuhan dan Pengembangan Karir $\left(\mathrm{X}_{1.1}\right)$ & 3,39 & Sedang \\
\hline 3. & Partisipasi Kerja $\left(\mathrm{X}_{1.2}\right)$ & 3,91 & Tinggi \\
\hline 4. & Sistem imbalan yang inovatif/ kompensasi $\left(\mathrm{X}_{1.3}\right)$ & 3,61 & Tinggi \\
\hline 5. & Lingkungan Kerja $\left(\mathrm{X}_{1.4}\right)$ & 3,92 & Tinggi \\
\hline
\end{tabular}

Mayoritas responden dalam penelitian ini memberikan penilaian tinggi terhadap variabel kualitas kehidupan kerja dengan rata-rata 3,74. Persepsi karyawan terhadap indikator paling tinggi adalah lingkungan kerja dengan rata-rata 3,92. Sedangkan penilaian terendah pada indikator pertumbuhan dan pengembangan karir dengan rata-rata 3,39.

Tabel 2 Rekapitulasi Analisis Diskriptif Variabel Kepuasan Kerja $\left(\mathbf{X}_{2}\right)$

\begin{tabular}{|c|l|c|c|}
\hline No & \multicolumn{1}{|c|}{ Variabel } & Mean & Keterangan \\
\hline 1. & Kepuasan Kerja $\left(\mathrm{X}_{2}\right)$ & 3,74 & Tinggi \\
\hline 2. & Kepuasan dengan gaji $\left(\mathrm{X}_{2.1}\right)$ & 3,68 & Tinggi \\
\hline 3. & Kepuasan dengan promosi $\left(\mathrm{X}_{2.2}\right)$ & 3,42 & Tinggi \\
\hline 4. & Kepuasan dengan rekan sekerja $\left(\mathrm{X}_{2.3}\right)$ & 3,89 & Tinggi \\
\hline 5. & Kepuasan dengan penyelia $\left(\mathrm{X}_{2.4}\right)$ & 3,85 & Tinggi \\
\hline 6. & Kepuasan dengan pekerjaan itu sendiri $\left(\mathrm{X}_{2.5}\right)$ & 3,97 & Tinggi \\
\hline
\end{tabular}

Mayoritas responden dalam penelitian ini memberikan penilaian tinggi terhadap variabel kepuasan kerja dengan rata-rata 3,74. Persepsi karyawan terhadap indikator paling tinggi adalah kepuasan dengan pekerjaan itu sendiri dengan rata-rata 3,97. Sedangkan penilaian terendah pada indikator kepuasan dengan promosi dengan rata-rata 3,42. 
Tabel 3 Rekapitulasi Analisis Diskriptif Variabel Kinerja (Y)

\begin{tabular}{|c|l|c|c|}
\hline No & \multicolumn{1}{|c|}{ Variabel } & Mean & Keterangan \\
\hline 1. & Kinerja $(\mathrm{Y})$ & 3,95 & Tinggi \\
\hline 2. & Kualitas Kerja $\left(\mathrm{Y}_{1}\right)$ & 3,93 & Tinggi \\
\hline 3. & Kuantitas Kerja $\left(\mathrm{Y}_{2}\right)$ & 4,08 & Tinggi \\
\hline 4. & Ketepatan Waktu $\left(\mathrm{Y}_{3}\right)$ & 3,76 & Tinggi \\
\hline 5. & Efektifitas Biaya $\left(\mathrm{Y}_{4}\right)$ & 4,08 & Tinggi \\
\hline 6. & Kebutuhan akan pengawasan $\left(\mathrm{Y}_{5}\right)$ & 4,05 & Tinggi \\
\hline 7. & Hubungan Antar Perorangan $\left(\mathrm{Y}_{6}\right)$ & 3,94 & Tinggi \\
\hline
\end{tabular}

Mayoritas responden dalam penelitian ini memberikan penilaian tinggi terhadap variabel kinerja dengan rata-rata 3,95. Persepsi karyawan terhadap indikator paling tinggi adalah kuantitas kerja dan efektifitas biaya dengan rata-rata 4,08. Sedangkan penilaian terendah pada indikator ketepatan waktu dengan rata-rata 3,76

\section{Analisis Kuantitatif}

\section{Analisis Pengaruh Kualitas Kehidupan Kerja terhadap Kinerja}

Berdasarkan perhitungan uji t Hipotesis pertama yang menyatakan terdapat hubungan positif dan signifikan antara kualitas kehidupan kerja terhadap kinerja tidak diterima atau tidak terbukti.

\section{Analisis Pengaruh Kepuasan Kerja terhadap Kinerja}

Berdasarkan perhitungan uji t Hipotesis kedua yang menyatakan terdapat hubungan positif dan signifikan antara kepuasan kerja terhadap kinerja diterima atau terbukti.

\section{Analisis Pengaruh Kualitas Kehidupan Kerja dan Kepuasan Kerja terhadap Kinerja}

Berdasarkan perhitungan uji $\mathrm{F}$ Hipotesis ketiga yang menyatakan ada hubungan signifikan antara kualitas kehidupan kerja dan kepuasan kerja secara bersama-sama terhadap kinerja karyawan diterima atau terbukti.

\section{Hasil Uji Asumsi Klasik}

Uji asumsi klasik digunakan untuk mendeteksi ada atau tidaknya penyimpangan asumsi klasik atas persamaan regresi berganda yang digunakan. Menurut Ghozali (2006:91) pengujian asumsi klasik meliputi uji multikolinieritas, autokolerasi, heterokedastisitas dan normalitas. Dari hasil pengujian menyatakan uji asumsi klasik semuanya terpenuhi.

\section{PEMBAHASAN}

\section{Pengaruh Kualitas Kehidupan Kerja terhadap Kinerja}

Berdasarkan hasil analisis dengan bantuan SPSS pada penelitian ini dapat dinyatakan bahwa kualitas kehidupan kerja berpengaruh tapi tidak signifikan terhadap kinerja. Peneliti melakukan beberapa wawancara terhadap supervisor mengenai faktor lain yang mempengaruhi kualitas kehidupan kerja terhadap kinerja karyawan shift PT Pertamina Persero RU IV Cilacap.

Menurut pernyataan Pak Alip sebagai Supervisor pekerja shift PT Pertamina Persero RU IV Cilacap dalam meningkatkan kinerja karyawan dalam pencapaian kualitas kehidupan 
kerjanya dibutuhkan dengan pengakuan diri. Hal tersebut sangat penting karena karyawan membutuhkan pengakuan diri dan ingin merasa dianggap. Sehingga karyawan akan merasa nyaman dalam bekerja. Hal ini sependapat dengan teori yang dikemukakan oleh Balaji (2013) yang mengemukakan bahwa Kualitas kehidupan kerja dipandang sebagai alternatif pendekatan pengendalian dalam mengelola karyawan. Karyawan melakukan pekerjaan lebih baik ketika mereka diizinkan untuk berpartisipasi dalam mengelola pekerjaan mereka dan membuat keputusan. Karyawan dianggap sebagai aset bagi organisasi bukan sebagai biaya.

Menurut pernyataan Pak Boedi sebagai Supervisor pekerja shift PT Pertamina Persero RU IV Cilacap dalam pengaruh kualitas kehidupan kerja terhadap peningkatan kinerja karyawan dibutuhkan dengan memperhatikan kondisi lingkungan sekitar agar terjalin sikap toleransi yang baik. Karena apabila sikap toleransi ditumbuhkan pada setiap karyawan akan menimbulkan kenyamanan dalam bekerja, hal tersebut akan mempengaruhi kinerja karyawan. Sehingga kualitas kehidupan dalam bekerja akan berjalan dengan baik. Hal ini tidak sejalan dengan Majumdar, Dawn \& Dutta (2012) yang menyimpulkan bahwa kedua variabel yaitu kualitas kehidupan kerja dan kinerja memiliki hubungan yang signifikan.

Jadi, kualitas kehidupan kerja dipengaruhi oleh faktor pemimpinnya, bagaimana seorang pemimpin bisa membina dan mengontrol dengan cara yang baik agar karyawan dapat berkinerja dengan baik. Apabila seorang pemimpin sukses dalam mengarahkan dan membimbing karyawannya dengan baik, maka karyawan akan melaksanakan kerja sesuai dengan peraturan yang ditetapkan dengan baik. Penelitian ini bertentangan dengan Beh \& Rose (2007) yang menyimpulkan bahwa variabel kualitas kehidupan kerja memiliki hubungan yang signifikan terhadap kinerja. Pengaruh lain yaitu penempatan posisi seseorang disesuaikan dengan minat, skill dan tingkat psikologis dari karyawan tersebut dalam menjalankan pekerjaan. Apabila karyawan merasa nyaman dalam penempatan posisi tersebut, maka karyawan akan semangat dalam bekerja.

Seperti yang telah diurai dalam penjelasan diatas, dapat dikatakan bahwa Kualitas kehidupan kerja dalam hal ini dipengaruhi oleh faktor lain seperti pengakuan diri, lingkungan kerja yang baik dan sikap saling toleransi, sikap pemimpin yang dapat membina dan mengontrol dengan baik, kemudian dalam hal penempatan posisi kerja yang tepat karena hal tersebut dapat berpengaruh pada kelangsungan kinerja karyawan. Dengan demikian diperlukan adanya program-program perbaikan yang sesuai agar kualitas kehidupan kerja dikemudian hari dapat meningkatkan kinerja karyawan bagian shift PT Pertamina Persero RU IV Cilacap.

\section{Pengaruh Kepuasan Kerja terhadap Kinerja}

Berdasarkan hasil analisis dengan bantuan SPSS pada penelitian ini dapat dinyatakan bahwa kepuasan kerja berpengaruh signifikan terhadap kinerja. Hasil penelitian sejalan dengan Ahmad, Ing \& Bujang (2014) yang menunjukkan bahwa ada hubungan yang signifikan antara faktor yang dipilih kepuasan kerja dan kinerja.

Menurut Sulistiyani dan Rosidah (2003:191) Kepuasan Kerja dapat mempengaruhi kehadiran seseorang dalam dunia kerja, dan ingin melakukan perubahan kerja, yang selanjutnya juga berpengaruh terhadap kemauan untuk bekerja. Dengan demikian, dalam penelitian ini kepuasan kerja merupakan salah satu aspek yang penting di dalam praktek manajemen sumber daya manusia, karena dapat mempengaruhi sikap kerja maupun kinerja 
karyawan. Hasil penelitian lain yang sejalan dikemukakan oleh Abdullah \& Wan (2013) juga menunjukkan bahwa kepuasan kerja memiliki hubungan yang signifikan terhadap kinerja.

Seperti yang telah diurai dalam teori tersebut, dapat dikatakan bahwa Kepuasan kerja dalam hal ini berkaitan dengan konsep perilaku organisasi dalam usahanya dilakukan pihak manajemen untuk meningkatkan kinerja karyawan tetap bagian shift PT Pertamina Persero RU IV Cilacap. Mengacu pada hasil diatas, benar adanya bahwa kepuasan kerja dan kinerja sangat berpengaruh dan dalam suatu perusahaan atau organisasi penting untuk diperhatikan. Karena kedua hal tersebut telah terbukti memiliki persepsi yang baik dari karyawan tetap bagian shift PT Pertamina Persero RU IV Cilacap.

\section{Pengaruh Kualitas Kehidupan Kerja dan Kepuasan Kerja secara simultan terhadap Kinerja Karyawan}

Berdasarkan hasil analisis dengan bantuan SPSS, maka dapat disimpulkan bahwa kualitas kehidupan kerja dan kepuasan secara bersama-sama mempunyai pengaruh yang signifikan terhadap kinerja karyawan. Penelitian ini sependapat dengan Husnawati (2006) yang menunjukkan bahwa kualitas kehidupan kerja mempengaruhi pengaruh langsung dan tidak langsung pada kinerja. Karena salah satu aspek terpenting dalam menciptakan suatu keunggulan bersaing adalah dengan meningkatkan kualitas sumber daya manusia yang dimiliki oleh perusahaan.

Pendapat Rivai dan Sagala (2009:856) Kepuasan Kerja pada dasarnya merupakan sesuatu yang bersifat individual. Setiap individu memiliki tingkat kepuasan yang berbedabeda sesuai dengan sistem nilai yang berlaku pada dirinya. Teori tersebut sejalan dengan penelitian ini. Makin tinggi penilaian terhadap kegiatan dirasakan sesuai dengan keinginan individu, maka makin tinggi kepuasannya terhadap kegiatan tersebut. Dengan demikian, kepuasan merupakan evaluasi yang menggambarkan seseorang atas perasaan sikapnya senang atau tidak senang, puas atau tidak puas dalam bekerja. Hasil penelitian sejalan dengan Arifin (2012) menyimpulkan bahwa kualitas kehidupan kerja sangat berpengaruh terhadap kinerjanya; kepuasan berpengaruh terhadap kinerja karyawan dan kualitas kehidupan kerja tidak berpengaruh terhadap kepuasan karyawan.

Seperti yang telah diurai dalam teori tersebut, dapat dikatakan bahwa Kualitas kehidupan kerja dipandang sebagai alternatif pendekatan pengendalian dalam mengelola karyawan. Apabila kualitas kehidupan kerja sudah diterapkan dengan baik, maka secara tidak langsung karyawan akan memiliki kepuasan tersendiri dalam melaksanakan setiap pekerjaan yang diemban, sehingga dapat meningkatkan kinerja setiap karyawan dengan baik dan dapat mencapai tujuan organisasi. Mengacu pada hasil diatas, benar adanya bahwa Kualitas kehidupan kerja dan kepuasan kerja terhadap kinerja karyawan pekerja shift PT Pertamina Persero Cilacap sangat berpengaruh dan dalam suatu perusahaan atau organisasi penting untuk diperhatikan. Karena hal tersebut telah terbukti memiliki persepsi yang baik dari karyawan tetap bagian shift PT Pertamina Persero RU IV Cilacap.

\section{PENUTUP}

\section{Kesimpulan}

Berdasarkan hasil analisis data melalui kuesioner yang disebarkan kepada karyawan tetap bagian shift PT Pertamina Persero RU IV Cilacap dan hasil wawancara kepada 3 
supervisor bagian shift PT Pertamina Persero RU IV Cilacap, maka dapat dikemukakan beberapa kesimpulan berikut: 1) Kualitas kehidupan kerja memiliki pengaruh positif tetapi tidak signifikan terhadap Kinerja karyawan PT Pertamina Persero RU IV Cilacap. Terdapat faktor lain yang mendukung, diantaranya adalah pengakuan diri, lingkungan kerja yang baik dan sikap saling toleransi, sikap pemimpin yang dapat membina dan mengontrol dengan baik, kemudian dalam hal penempatan posisi kerja yang tepat karena hal tersebut dapat berpengaruh pada kelangsungan kinerja karyawan. 2) Kepuasan kerja memiliki pengaruh positif dan signifikan terhadap Kinerja karyawan PT Pertamina Persero RU IV Cilacap. 3) Kualitas Kehidupan kerja dan Kepuasan kerja memiliki pengaruh positif dan signifikan terhadap Kinerja karyawan PT Pertamina Persero RU IV Cilacap.

\section{Saran}

Berdasarkan hasil analisis dan pembahasan di atas, adapun saran untuk PT Pertamina Persero RU IV Cilacap, yaitu: 1) Menjaga kualitas kehidupan kerja karyawan mencakup aktifitas-aktifitas yang ada di dalam perusahaan dengan memperhatikan faktor lain yang mendukung. Hal tersebut dapat meningkatkan suatu kondisi kehidupan kerja yang dapat membangkitkan semangat kerja dan kinerja yang lebih baik dalam melaksanakan tugas demi mencapai sasaran perusahaan. 2) Menjaga kondisi dimana karyawan sebelum ditugaskan sesuatu harus mengetahui dengan pasti apa, bagaimana, dimana dan seperti apa tugas yang harus mereka kerjakan. 3) Mempertahankan apa yang mendasari seorang karyawan memiliki tingkat kepuasan dalam bekerja. Karena apabila tingkat kepuasan kerja tinggi, maka akan memberikan dampak yang baik pada kinerjanya.

\section{DAFTAR PUSTAKA}

Abdullah, Alkhaliel Adeeb \& Wan, Hooi Lai.2013. Relationships of Non-Monetary Incentives, Job Satisfaction and Employee Job Performance. Journal Business And Economics-Management. Vol.2;Proquest.pg.1085-1091.

Ahmad, Rusli; Ing, Hii Ee; Bujang, Sopian. 2014. Relationship Between Selected Factors of Job Satisfaction and Job Performance Among Workers at Palm Oil Industries. Journal Business And Economics-Management. Vol.3;Proquest. pg.1751-1766.

Arifin, Noor. 2012. Analisis Kualitas Kehidupan Kerja, Kinerja, dan Kepuasan Kerja pada CV Duta Senenan Jepara. Jurnal Economia, Volume 8, Nomor 1.

Balaji, R. 2004. A Study on Quality of Worklife among Employees, International Journal of Innovative Research in Science, Engineering and Technology, Vol.2, Issue 2.

Beh, LooSee;Rose, Raduan Che. 2007. "Linking QWL and Job Performance”: Implications for Organizations, Performance Improvement; 46, 6; Proquest pg.30.

Bernadin,H. John \& Russel, Joyce E.A. 2003. Human Resource Management (An Experimental Edition). Mc Grawhill Inc : Singapore.

Cascio, F., Wayne . 1998. Managing Human Resources: Productivity, Quality of Work Life, Profits. Fifth Edition.New York: The McGraw-Hill Companies, Inc. 
Cascio, F., Wayne. 2006. Managing Human Resources. Colorado: Mc Graw -Hill.

Ghozali, Imam. (2006). Aplikasi Analisis Multivariate dengan Program SPSS. Semarang: Badan Penerbit Universitas Diponegoro.

Hasibuan, Malayu S.P. 2013. Manajemen Sumber Daya Manusia. Edisi Revisi. PT Bumi Aksara. Jakarta.

Husnawati, A. 2006. Analisis Pengaruh Kualitas Kehidupan Kerja Terhadap Kinerja Karyawan Dengan Komitmen dan Kepuasan Kerja Sebagai Intervening Variabel (Studi Pada PERUM Pegadaian Kanwil VI Semarang), Tesis Magister Manajemen (Tidak dipublikasikan), Semarang : Program Pascasarjana Universitas Diponegoro.

Majumdar, Malini Nandi; Dawn, Debosmita \& Dutta, Avijan. 2012. Impact Of Quality WorkLife On Job Performance: A Case Study On Indian Telecom Sector. International Journal of Arts \&Sciences.Vol.5 ;Proquest.pg. 655-685.

Mangkunegara, Anwar Prabu. 2010. Evaluasi Kinerja SDM.PT. Refika Aditama, Bandung.

Pruijt, Hans (2003) "Performance and Quality of Work Life", Journal of Organizational Change Management.Vol. 13. p.389-400.

Rivai, Veithzal dan Sagala, Ella Jauvani. 2009. Manajemen Sumber Daya Manusia untuk Perusahaan: Dari Teori ke Praktik. PT RajaGrafindo Persada, Jakarta.

Robbins, Stephen P. (2002), Prinsip-Prinsip Perilaku Organisasi, Penerbit Erlangga, Jakarta. Sekaran, Uma. 2006. Metodologi Penelitian Untuk Bisnis. Jakarta : Salemba Empat.

Sugiyono. 2009. Metode Penelitian Kuantitatif, Kualitatif dan R\&D. Alfabeta, Bandung.

Sulistiyani, Ambar Teguh \& Rosidah. 2003. Manajemen Sumber Daya Manusia: Konsep, Teori dan Pengembangan dalam Konteks Organisasi Publik. Graha Ilmu.

Walton, R. E. 1974. QWL indicators: Prospects and problems. In Measuring the quality of Working Life: A Symposium on Social Indicators of Working Life (March, pp: 19-20) edited by A. H. G. Portigal. Ottawa.

Zin, Razali Mat, 2004, “Perception of Professional Engineers Toward Quality of Work Life and Organizational Commitment”, Gajahmada International Journal of Business, Vol. 6. No. 3, p.323-334. 
